Images in...

\title{
Cytomegalovirus-induced haemophagocytic lymphohistiocytosis syndrome
}

\author{
Javier Munoz, ${ }^{1}$ Naushin Shareef, ${ }^{2}$ Vijayalakshmi Donthireddy ${ }^{1}$ \\ ${ }^{1}$ Haematology-Oncology Department, Henry Ford Hospital, Detroit, Michigan, USA; \\ 2Internal Medicine Department, Henry Ford Hospital, Detroit, Michigan, USA \\ Correspondence to Dr Javier Munoz, javier.munoz@me.com
}

\section{DESCRIPTION}

A 24-year-old female presented with fever and abdominal pain for 1 week. Her medical history included seizures secondary to tuberous sclerosis controlled with lamotrigine and Crohn's disease in remission for the last 2 years treated with 6-mercaptopurine. On presentation, she was found to have pancytopenia and elevated liver enzymes. Physical examination was significant for a petechial rash. Peripheral blood smear showed atypical lymphocytes (figure 1A). Serology was positive for Ig M cytomegalovirus with an elevated viral load of 82392 copies/ml. HIV testing was negative. Her clinical course was complicated by acute respiratory distress requiring mechanical ventilation. The patient denied history of repeated infections during childhood, any relevant family history or sick contacts. A bone marrow aspirate revealed increased benign-appearing histiocytes (figure $1 \mathrm{~B}$ ) with phagocytosis (figure 1C) of erythrocytes, leucocytes and platelets. The soluble interleukin-2 receptor was 25568 units $/ \mathrm{ml}$. There were insufficient natural killer cells to evaluate for perforin expression. Genetic testing for familial haemophagocytic lymphohistiocytosis (HLH) including Perforin 1, Munc134, Syntaxin 11 were negative. Treatment was initiated with intravenous ganciclovir and intravenous immunoglobulin. Simultaneously, immunochemotherapy with HLH-2004 protocol was administrated with dexamethasone, etoposide and cyclosporine for 8 weeks with rapid clinical improvement to the point of no longer requiring life support and concomitant resolution of her pancytopenia. The patient remains in complete remission 6 months after her initial diagnosis and is currently being evaluated for possible stem cell transplantation.

Competing interests None.

Patient consent Obtained.

\section{REFERENCES}

1. Shabbir M, Lucas J, Lazarchick J, et al. Secondary hemophagocytic syndrome in adults: a case series of 18 patients in a single institution and a review of literature. Hematol Oncol 2011;29:100-6.
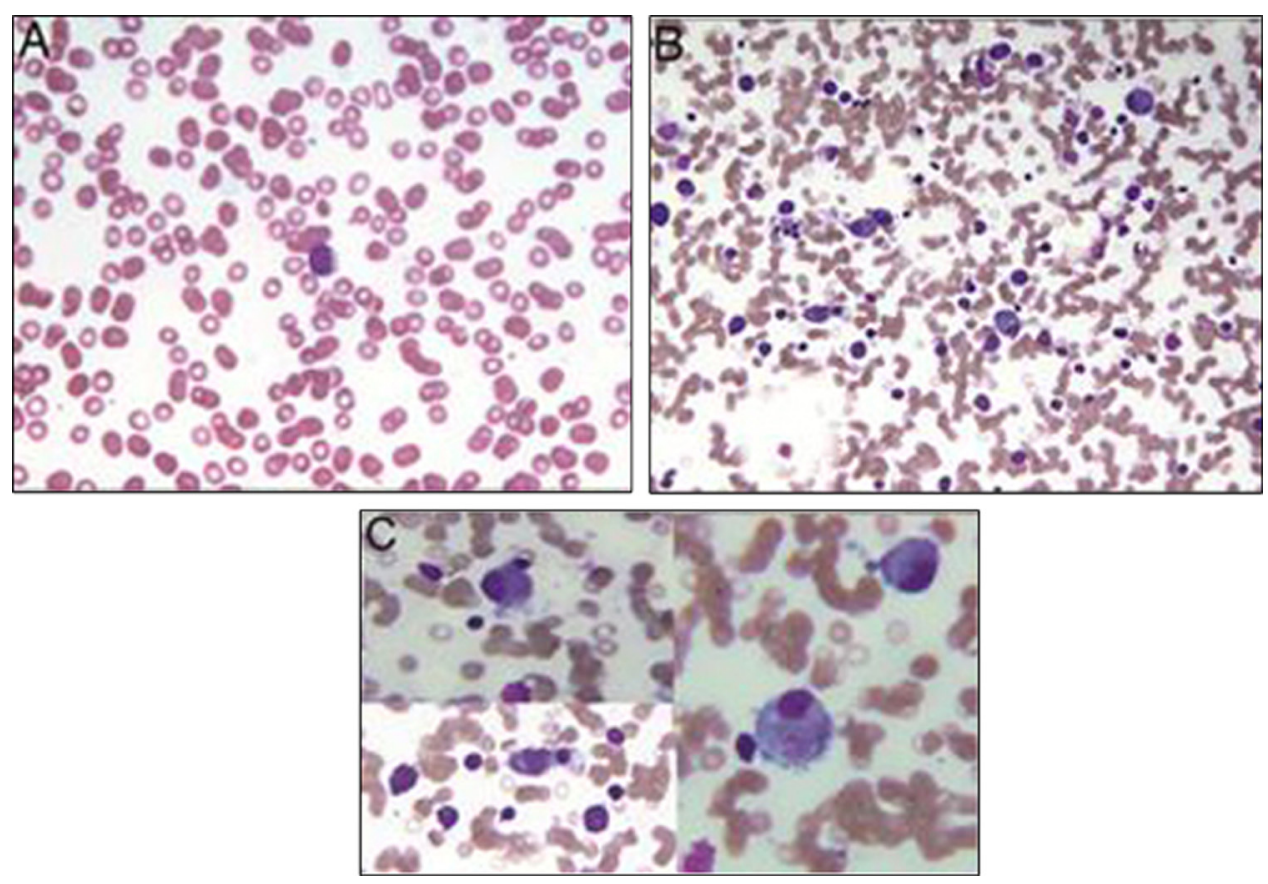

Figure 1 Peripheral blood smear showed atypical lymphocytes $(A)$. A bone marrow aspirate revealed increased benign-appearing histiocytes (B) with phagocytosis of erythrocytes (C). 


\section{BMJ Case Reports}

2. Sakamoto 0, Ando M, Yoshimatsu S, et al. Systemic lupus erythematosus complicated by cytomegalovirus-induced hemophagocytic syndrome and colitis. Intern Med 2002;41:151-5.
3. Tang YM, Xu XJ. Advances in hemophagocytic lymphohistiocytosis: pathogenesis, early diagnosis/differential diagnosis, and treatment. ScientificWorldJournal 2011:11:697-708.

This pdf has been created automatically from the final edited text and images.

Copyright 2012 BMJ Publishing Group. All rights reserved. For permission to reuse any of this content visit http://group.bmj.com/group/rights-licensing/permissions.

BMJ Case Report Fellows may re-use this article for personal use and teaching without any further permission.

Please cite this article as follows (you will need to access the article online to obtain the date of publication).

Munoz J, Shareef N, Donthireddy V. Cytomegalovirus-induced haemophagocytic lymphohistiocytosis syndrome. BMJ Case Reports 2012; 10.1136/bcr.10.2011.4963, Published XXX

Become a Fellow of BMJ Case Reports today and you can:

- Submit as many cases as you like

- Enjoy fast sympathetic peer review and rapid publication of accepted articles

- Access all the published articles

- Re-use any of the published material for personal use and teaching without further permission

For information on Institutional Fellowships contact consortiasales@bmjgroup.com

Visit casereports.bmj.com for more articles like this and to become a Fellow 